\title{
REVIEW
}

\section{The mental health of refugee children}

\section{Fazel, A Stein}

The UK is facing a major increase in the number of people seeking asylum each year, of whom approximately a quarter are children. The stressors to which refugees are exposed are described in three stages: (1) while in their country of origin; (2) during their flight to safety; and (3) when having to settle in a country of refuge. The evidence concerning the impact of displacement on children's mental health is reviewed and a framework for conceptualising the risk factors is proposed. The available literature shows consistently increased levels of psychological morbidity among refugee children, especially post-traumatic stress disorder, depression, and anxiety disorders. The principles underlying the delivery of mental health care for these children are also considered. It is argued that much primary prevention can be undertaken in the school context. Some key aspects of British immigration law are examined and the tension between the law and the best interests of the child principle is discussed. There is particular concern for the plight of unaccompanied children. Attention to the mental health needs of this vulnerable group is urgently required.
See end of article for authors' affiliations

Dr M Fazel, University Department of Psychiatry, Warneford Hospital Oxford OX3 7JX, UK mina.fazel@psych.ox.ac.uk

Accepted 25 July 2002

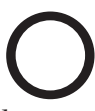
ne per cent of the world's population, 50 million people, are currently uprooted-23 million are refugees who have sought safety in another country, and 27 million are displaced within their own country. ${ }^{1}$ In the past decade the worldwide refugee population has increased tenfold and all indicators show that this number will continue to rise. ${ }^{2}$ (A refugee is defined as: a person who, "owing to a well-founded fear of being persecuted for reasons of race, religion, nationality, membership of a particular social group or political opinion, is outside the country of his nationality and is unable or, owing to such fear, is unwilling to avail himself of the protection of that country; or who, not having a nationality and being outside the country of his former habitual residence as a result of such events, is unable or, owing to such fear is unwilling to return to $\mathrm{it}^{\prime \prime} .{ }^{3}$ ) The UK is facing a major increase in the number of people seeking asylum, with 100000 applications made in the year 2000, representing a $250 \%$ increase in just four years. ${ }^{4}$ However, other countries are facing more formidable challenges; for example, Tanzania in 1999 received more refugees than the whole of Western Europe combined. ${ }^{1}$

Over half of the world's displaced population are children. In the past 10 years it is estimated that more than two million children have been killed in conflict, with a further six million wounded and one million orphaned. ${ }^{5}$ The 1989 UN Convention on the Rights of the Child offers an important theoretical and legal framework for the protection of children; however, national immigration law is often the arena where human rights and national self interests clash and the principle of promoting the best interests of refugee children can be overlooked. Refugee children are at significant risk of developing psychological problems, and although in the UK they will have arrived in one of the richest countries in the world, the services potentially available to help them are often ill equipped to address their needs, and imminent legislation might even exacerbate their problems.

\section{THREE STAGES OF TRAUMATIC EXPERIENCES}

The stresses to which most refugees are exposed can be understood as occurring at three different stages: (1) while in their country of origin; (2) during the flight to safety; and (3) when having to settle in a country of refuge. ${ }^{6}$

(1) In their native countries many refugees have experienced considerable trauma. They have often been forced to flee their homes because of exposure war or combat and hence witnessed violence, torture, and losses of close family and friends. Refugee children might have no memory of a period of stability; their school education, if any, is likely to have been disrupted; and parental distress and general insecurity are common experiences. $^{7}$

(2) The journey to a country of refuge can also be a time of further stress. It can take many months and expose the refugees to more life threatening dangers. Refugee children at these times can experience separation from parents, either by accident or as a strategy to ensure their safety. As international immigration controls tighten, more children are being placed in the hands of smugglers to ensure their escape, either as the only representative their family can afford to send away or in the hope that the child alone would have better chances of gaining refugee status. $^{8}$

(3) The final stage of finding respite in another country can be a time of additional difficulty as many have to prove their asylum claims and also try to integrate in a new society. This period is being increasingly referred to as a period of "secondary trauma" to highlight the problems encountered. On arriving, a refugee child will need to settle into a new 
Table 1 Risk factors for mental health problems in refugee children
Parental factors
Post-traumatic stress disorder (PTSD) in either parent ${ }^{49}$
Maternal depression ${ }^{24}$
Torture, especially in mother ${ }^{14}$
Death of or separation from parents ${ }^{24} 50$
Direct observation of the helplessness of parents ${ }^{12} 14$
Underestimation of stress levels in children by parents ${ }^{5}$
Unemployment of parents ${ }^{12}$
Child factors
Number of traumatic events - either experienced or witnessed ${ }^{52}$
Expressive language difficulties ${ }^{14}$
PTSD leading to long term vulnerability in stressful situations ${ }^{53}$
Physical health problems from either trauma or malnutrition ${ }^{54}$
Older age ${ }^{12}$
Environmental factors
Number of transitions ${ }^{36}$
Poverty ${ }^{6}$
Time taken for immigration status to be determined ${ }^{55}$
Cultural isolation ${ }^{24}$
Period of time in a refugee camp ${ }^{14}$
Time in host country (risk possibly increases with time) ${ }^{21}$

school and find a peer group. Children might have to prematurely assume adult roles; for example, as a vital language link with the outside world.

\section{PSYCHOLOGICAL IMPLICATIONS OF DISPLACEMENT FOR CHILDREN}

There is considerable evidence that refugee children are at significant risk of developing psychological disturbance as they are subject to a number of risk factors. Table 1 provides a framework for conceptualising these risk factors. Refugee children suffer both from the effects of coming from a war zone and of adjusting to an unfamiliar culture. These stressors also affect their families. ${ }^{10}{ }^{11}$ Moreover, consistent research findings show that as the number of risk factors accumulates for children, the likelihood that they will develop psychological disturbance dramatically increases. ${ }^{12}$ In particular, Rutter has shown the synergistic effects of multiple risk factors on adverse child outcome. ${ }^{11}$

Studies of children in exile show that the prevalence of emotional and behavioural disorders is high, with the most frequent diagnostic categories being post-traumatic stress disorder (PTSD), anxiety with sleep disorders, and depression. The incidence of these disorders is difficult to estimate but most studies have found significantly raised levels of disturbance compared to control populations. For example, studies of newly arrived refugee children show rates of anxiety from $49 \%$ to $69 \%,{ }^{13-17}$ with prevalence dramatically increasing if at least one parent had been tortured or if families have been separated. Table 2 lists common presenting symptoms of the different disorders. ${ }^{18}$ Children, however, often present with a mixture of the symptoms listed and not necessarily fulfilling a single diagnostic category, for example with a mixture of post-traumatic and depressive symptomatology.

Cambodian refugees are the most widely studied group; in a study of 46 children followed up over a number of years, $47 \%$ had an Axis 1 diagnosis and comorbidity was common. In particular this study found rates of PTSD at $40 \%$, depression at $21 \%$, and anxiety at $10 \%$. Three years later, levels were still high, with $48 \%$ manifesting PTSD and $41 \%$ depression. After six years, PTSD was still prominent and a strong relation was found between PTSD and later stressful events, suggesting that the child is left more vulnerable to later traumatic experiences. ${ }^{16}{ }^{19-21}$
Table 2 Summary of common presenting symptoms of psychological disorders in refugee children

Post-traumatic stress disorder

Persistent avoidance of stimuli: specific fears; fear of being alone; withdrawal

Re-experiencing aspects of the trauma: nightmares; visual images; feelings of fear and helplessness

Persistent symptoms of increased arousal: easily aroused;

disorganised and agitated behaviour; lack of concentration

Other anxiety symptoms

Marked anxiety and worry: irritability, restlessness

Other sleep disorders

Somatic symptoms including headaches and abdominal pain

Depression

Low mood

Loss of interest or pleasure

Declining school performance

Conduct disorders

Some studies have attempted to identify protective factors that enable children at high risk to be more resilient. These include: (1) a supportive family milieu; (2) an external societal agency that reinforces a child's coping efforts; and (3) a positive personality disposition. ${ }^{12}$ The response and functioning of a parent during and after stress can also have a profound effect on child behaviour. ${ }^{22}$ Brown and Harris found a greater vulnerability to depression in adults who lost a parent in childhood, and that the key predictor of this vulnerability was the quality of care giving the child received after the loss itself. ${ }^{22 a}$

In addition to the mental health needs of refugee children, there have been studies that have highlighted considerable physical health problems. A study of newly arrived refugee children in New York showed that $30 \%$ had conditions that required further medical attention..$^{23}$ Anaemia, parasitic infections, and dental caries were the most frequently presenting problems; in addition, $43 \%$ were positive for hepatitis B surface antigen and $20 \%$ were found to be latently infected with the tuberculosis bacterium. Another study in Sweden found $15 \%$ of refugee children had iron deficiency anaemia. ${ }^{13}$

\section{PRINCIPLES OF MENTAL HEALTH CARE}

When planning for the mental health needs of refugee children, two main areas need targeting: firstly, the provision of appropriate help for those experiencing psychological difficulties; and secondly, to pay attention to develop primary prevention strategies to this high risk group.

Traumatic events can have an effect on a child's emotional, cognitive, and moral development because they influence the child's self perceptions and expectations of others. However, finding appropriate ways to treat these problems is hampered by the lack of reliable evidence for the effectiveness of clinical therepeutic interventions with refugee children as most of the research has been conducted following single traumatic events (such as floods, single school shootings). Many refugee children, however, have experienced prolonged and repeated trauma.

The general consensus is that there is a need for a variety of different treatments, including individual, family, group, and school based interventions. ${ }^{24}{ }^{25}$ Cognitive behavioural treatment for single traumatic events has been used, ${ }^{26}{ }^{27}$ and a number of case series and single case studies have reported good results for treatments including play, art, music therapy, and story telling. ${ }^{24}{ }^{27-29}$ Of added significance are the post-traumatic symptoms of parents and the impact of these on their capacity to parent. ${ }^{30}$ 
Table 3 Possible impact of aspects of existing and imminent immigration law on the mental health of refugee children

\begin{tabular}{|c|c|c|}
\hline Policy aspects & Description and background & $\begin{array}{l}\text { Example of possible impact on } \\
\text { children }\end{array}$ \\
\hline Dispersal & $\begin{array}{l}\text { Refers to a forced resettlement of } \\
\text { asylum seekers } \\
\text { If a refugee decides not to move they } \\
\text { then lose entitlement to benefits and } \\
\text { accommodation }\end{array}$ & $\begin{array}{l}\text { Yet one more forced relocation for } \\
\text { children and moves children away } \\
\text { from a school they might have settled } \\
\text { in } \\
\text { Can be moved to an area without } \\
\text { important statutory and non-statutory } \\
\text { services }\end{array}$ \\
\hline Accommodation centres & $\begin{array}{l}\text { New pilot policy to build three } \\
\text { accommodation centres for up to } 750 \\
\text { asylum seekers to live until their status } \\
\text { is determined }\end{array}$ & $\begin{array}{l}\text { Children for first six months to be } \\
\text { educated on these sites and away } \\
\text { from mainstream education }\end{array}$ \\
\hline Reporting centres & $\begin{array}{l}\text { Centres to be set up throughout the } \\
\text { country, where refugees will have to } \\
\text { report in person at regular intervals }\end{array}$ & $\begin{array}{l}\text { Adds to the uncertainty of the refugee } \\
\text { determination process and inability of } \\
\text { families to settle, as each reporting } \\
\text { time might imply sudden departure to } \\
\text { an unknown destination }\end{array}$ \\
\hline Detention centres & $\begin{array}{l}\text { The government goal is to be able to } \\
\text { detain up to } 4000 \text { asylum seekers. In } \\
2001 \text {, four new detention centres } \\
\text { were built, increasing the total in the } \\
\text { UK to eight }\end{array}$ & $\begin{array}{l}\text { Detention of children under the age of } \\
16 \text { is against British law; however, } \\
\text { this is being increasingly ignored for } \\
\text { asylum seeking children } \\
\text { No statutory provision for those that } \\
\text { are detained }\end{array}$ \\
\hline Tighter immigration controls & $\begin{array}{l}\text { Placing a fine on carriers } \\
\text { Improving border controls, e.g. } \\
\text { gamma scanners }\end{array}$ & $\begin{array}{l}\text { Greater likelihood to turn to illegal } \\
\text { and/or dangerous means to enter the } \\
\text { country, and exposure to other forms } \\
\text { of abuse by traffickers }\end{array}$ \\
\hline
\end{tabular}

No studies have evaluated the benefit of group treatments, however, based on evidence for groups in other circumstances, it would appear that this may be a good way to help children develop a sense of coping and mastery and sharing ways of solving common problems. ${ }^{26}$ A number of children's disorders could be addressed directly; for example, many suffer from depression and common sleep problems for which psychotherapeutic treatments and medication are available. ${ }^{3132}$

Addressing the treatment needs of refugee children can often seem overwhelming to those involved as they do not easily fit with prescribed care packages ${ }^{28}$ and often require working with many different professionals and agencies such as interpreters, legal/immigration teams, voluntary organisations, ethnic support groups, social services, and schools. This unavoidably requires more time and resources. ${ }^{27}{ }^{33}$ Successful programmes emphasise the role of cross-cultural teams who can work in an extended outreach manner. ${ }^{27}$ Some programmes have also tried to integrate traditional healing methods to try and enhance the effectiveness of treatment. ${ }^{29}$ Home based or school based work has advantages with families who might have a lingering distrust of authority.

\section{Importance of schools}

A vital aspect of care for refugee children is in primary prevention; schools are uniquely placed to undertake such work. The goals of primary prevention can include enhancing resilient behaviours in children; schools offer an excellent framework for this, as well as monitoring of academic progress, and behavioural and social adaptation. ${ }^{31334}$ Schools provide a place to learn, facilitate the development of peer relationships, and help provide a sense of identity. ${ }^{35}{ }^{36}$ In particular, for refugee children, schools can play a vital part in their integration by becoming an anchor, not only for educational but also for social and emotional development, and as an essential link with the local community for children and parents. There is good evidence that a proportion of children at high risk of developing long term psychological sequelae do however become competent young adults. One of the key protective factors in influencing this outcome is the school that acts as a stable social support. ${ }^{37}$ This support helps to develop children's resilience by enhancing their individual competencies, in turn adding to their self worth and sense of control over their environment. ${ }^{38}$

\section{TENSIONS BETWEEN BRITISH IMMIGRATION LAW AND THE BEST INTERESTS PRINCIPLE}

The rights of asylum seeking children in the UK are limited. When the UK government ratified the UN Convention on the Rights of the Child in 1991, it entered a reservation in applying this legislation to refugee children "in so far as it relates to the entry into, stay in, and departure from the UK on those who do not have the right under the law of the UK to enter and remain in the $\mathrm{UK}^{\prime \prime}{ }^{7}$ This reservation is one of the rare areas of UK law concerning children where the best interests principle does not play a part or where the protection of the child is not the paramount concern.

The UK ranks ninth among European countries in terms of asylum seekers per head of population. ${ }^{4}$ Statistics from the year 2000 show that the largest numbers arriving in the UK were from Iraq, Sri Lanka, the Federal Republic of Yugoslavia, Iran, and Afghanistan. Less than one third of asylum applications were allowed to stay (for example, $11 \%$ were granted full refugee status and 23\% Exceptional Leave to Remain-a status which is reviewed after five years). ${ }^{49}$

Since the influx of refugees into Britain significantly increased following the Balkan conflict there have been four major changes in UK National Immigration law in eight years. The most recent change in the 2001-02 parliamentary session has placed new emphasis on induction centres, accommodation centres, reporting centres, and rapid removals. The policy of dispersing asylum seekers around the country will continue and the number of places in detention centres will increase fourfold..$^{40}$

The thrust of these changes has been to deter non-political refugees from entering Britain. Whether it has achieved this 
objective is unclear; however, it is evident that it has made life much "less welcoming" for those who have entered the country. The possible impact of these policies on children can be substantial and needs to be carefully planned (see table 3 ). For example, the government has stated that it is "committed to removals and the use of dedicated detention facilities", but how this can be done humanely, especially when children are involved, needs careful consideration. In fact, it may be that such removals may infringe children's rights.

When considering the impact of the dispersal system on refugee children, this newer government policy may have further aggravated their plight. The aim of this policy is to lift the burden of numbers away from the southeast of England. However, it disrupts the education and stability of children who have been placed in local schools by forcing them to move suddenly or risk losing any rights to future support. School transition is a significant event for any child and can lead to a decline in the perception of support from school ${ }^{41}$; frequent relocation is associated with failing academic achievement and behavioural difficulties. ${ }^{36}{ }^{42} 43$

\section{Unaccompanied children}

A particularly vulnerable group of refugee children are those who are "unaccompanied" and defined as "separated from both parents and for whose care no person can be found who by law or custom has primary responsibility". ${ }^{78}$ The numbers of unaccompanied children are rising significantly in Western countries and are estimated to comprise $2-5 \%$ of any refugee population. At any one time there may be up to 100000 separated children in Western Europe alone. Their vulnerabilities are not only because they are bereft of support systems such as family and often community life, ${ }^{12}{ }^{20}$ but also because they are at increased risk of neglect, sexual assault, and other abuses. ${ }^{44}$ It may, however, be that the kind of children that manage to get to the UK in the face of all the adversity are a relatively resourceful and resilient group. ${ }^{8}$

The smuggling of children across borders has become a growing international concern. Children can be exposed to potential abuse and exploitation en route or in the country of destination. The children often arrive with false documents or with no papers at all. Many are unwilling or unable to tell their age. ${ }^{8}$ Relatively few separated children applying for asylum are awarded refugee status; the average recognition rate in 1999 for Europe was around 5\%. In the UK the majority are granted Exceptional Leave to Remain up to the age of 18 when their status is reviewed. While this provides temporary protection, it leaves the child with major uncertainties about his/her future that can be emotionally demanding as well as having significant consequences on education and integration. ${ }^{8}$

\section{INTERNATIONAL AGENDA}

A number of United Nations Charters have addressed the needs of refugee children underlining the principle of the universality of the rights of children. These include the UN Convention on Refugees, ${ }^{45}$ the Universal Declaration of Human Rights (Article 14 (1) states that "everyone has the right to seek and to enjoy in other countries asylum from persecution" $)^{46}$ and the 1989 UN Convention on the Rights of the Child (Article 22 tries to ensure that refugee children should have the same rights as citizen children). ${ }^{47}$ All countries except the United States and Somalia have ratified the latter Convention.

It is now widely recognised that children may be refugees in their own right. In 1996, Canada's Immigration and Refugee Board issued Guidelines on Child Refugee Claimants, the first produced by any country operating a refugee determination system. ${ }^{48}$ Two years later, the United States Immigration Service published its own Guidelines for Children's Asylum Claims. Both recognise that children may experience persecution differently from adults, and that child sensitive status determination procedures are needed. Important aspects include special training for refugee determination officials, legal representatives, guardians, interpreters, and others who come in contact with children to understand the principles and standards of the Convention on the Rights of the Child and other international laws. They need to have knowledge of the children's countries of origin and of relevant cultural issues. Learning how to conduct child sensitive interviews, especially with children who might have experienced previous trauma, can help to ensure that children's needs are properly assessed and addressed.

\section{CONCLUSION}

The multidimensional effects of trauma on children and their families are compounded by forced uprooting, multiple losses, and the myriad changes brought about by migration. ${ }^{28}$ Children as a group have greater dependence on outside sources for their protection and care and have their own specific developmental and emotional needs. However, immigration law in the UK does not appear to have always taken account of the best interests of these children. ${ }^{47}$ Refugee children are a silent group that are easily overlooked. Attention to the mental health needs of this vulnerable group by government and other policy makers is urgently required.

\section{ACKNOWLEDGEMENTS}

We are grateful to the charity Action for Children in Conflict for funding our work with refugee children and to Professor Guy Goodwin-Gill for his helpful comments on the manuscript.

\section{Authors' affiliations}

M Fazel, Lecturer in Child and Adolescent Psychiatry, University Department of Psychiatry, University of Oxford, UK

A Stein, Professor of Child and Adolescent Psychiatry, University Department of Psychiatry, University of Oxford, UK

\section{REFERENCES}

1 UNHCR. Statistics. http://www.unhcr.ch/statist/main.htm, 2001.

2 UNHCR. The state of the world's refugees, 2000. Oxford: Oxford University Press, 2000.

3 United Nations. Convention Relating to the Status of Refugees, 1951

4 Matz D, Hill R, Heath T. Asylum statistics, United Kingdom, 2000. London: Immigration, Research and Statistics Service, Home Office, 2001.

5 UNICEF. The state of the world's children. Oxford: Oxford University Press, 1996.

6 Hodes M. Psychologically distressed refugee children in the United Kingdom. Child Psychology and Psychiatry Review 2000:5:57-68.

7 Russell S. Most vulnerable of all: the treatment of unaccompanied refugee children in the UK. UK: Amnesty International, 1999.

8 Ayott L, Williamson L. Separated children in the UK: an overview of the current situation. London: The Refugee Council and Save the Children, 2001.

9 Richman N. Refugees and asylum seekers in the West. In: Bracken P, Petty C, eds. Rethinking the trauma of war. New York: Free Association Press, 1998: 170-86.

10 Werner EE, Smith RS. Vulnerable but invincible: a longitudinal study of resilient children and youth. New York: McGraw Hill, 1982.

11 Rutter ML. Psychosocial adversity and child psychopathology. $\mathrm{Br} J$ Psychiatry 1999;1 174:480-93

12 Garmezy N, Masten AS. Chronic adversities. In: Rutter M, Taylor EA, Hersov LA, eds. Child and adolescent psychiatry: modern approaches. Oxford: Blackwell Scientific, 1994:191-208.

13 Hiern A, Kocturk-Runefors T, Jeppson $O$, et al. Health and nutrition in newly resettled refugee children from Chile and the Middle East. Acta Paediatr Scand 1991;80:859-67.

14 Montgomery E. Refugee children from the Middle East. Scand J Soc Med Suppl 1998:54:1-152.

15 Kinzie JD, Sack RL, Angell R, et al. The psychiatric effects of massive trauma on Cambodian children. J Am Acad Child Adolesc Psychiatry 1986;25:370-6.

16 Kinzie JD, Boehnlein JK, Leung PK, et al. The prevalence of posttraumatic stress disorder and its clinical significance among Southeast Asian refugees. Am J Psychiatry 1990;147:913-17.

17 Cohn J, Danielsen L, Holzer KI, et al. A study of Chilean refugee children in Denmark. Lancet 1985;2:437-8.

18 American Psychiatric Association. Diagnostic and statistical manual of mental disorders, 4th edn. Washington, DC: American Psychiatric Association, 1994. 
19 Sack WH, Clarke G, Him C, et al. A 6-year follow-up study of Cambodian refugee adolescents traumatized as children. J Am Acad Child Adolesc Psychiatry 1993;32:431-7.

20 Boehnlein JK, Kinzie JD, Ben R, et al. One-year follow-up study of posttraumatic stress disorder among survivors of Cambodian concentration camps. Am J Psychiatry 1985; 142:956-9.

21 Kinzie JD, Sack W, Angell R, et al. A three-year follow-up of Cambodian young people traumatized as children. J Am Acad Child Adolesc Psychiatry 1989;28:501-4

22 Masten A, Best K, Garmezy N. Resilience and development: contributions from the study of children who overcome adversity. Dev Psychopathol 1990;2:425-44.

22a Brown GW, Harris TO, Bifulco A. Long-term effects of early loss of parent. In: Rutter M, Izard CE, Read PB, eds. Depression in young people: developmental and clinical perspectives. New York: Guilford, 1986:251-96.

23 Meropol SB. Health status of pediatric refugees in Buffalo, NY. Arch Pediatr Adolesc Med 1995;149:887-92.

24 McCloskey LA, Southwick K. Psychosocial problems in refugee children exposed to war. Pediatrics 1996;97:394-7.

25 Jensen SB, Shaw J. Children as victims of war: current knowledge and future research needs. J Am Acad Child Adolesc Psychiatry 1993;32:697-708

26 Yule W, Willams C. Post-traumatic stress reactions in children. J Trauma Stress 1997; 3:279-95

27 Ahearn FL, Athey JL. Refugee children: theory, research and services. Baltimore, MD: John Hopkins University Press, 1991

28 Woodcock J. Refugee children and their families: theoretical and clinical perspectives. In: Dwivedi K, ed. Post traumatic stress disorder in children and adolescents. London: Whurr, 2000:213-39.

29 Knox J. Homebased services for Southeast Asian refugee children: a process and formative evaluation. Children and Youth Services Review 1996; 18:553-78.

30 Almqvist K, Broberg AG. Mental health and social adjustment in young refugee children 31 12 years after their arrival in Sweden. J Am Acad Child Adolesc Psychiatry 1999;38:723-30.

31 Yule W. From pogroms to "ethnic cleansing": meeting the needs of war affected children. J Child Psychol Psychiatry 2000;41:695-702

32 Pynoos RS, Kinzie JD, Gordon M. Children, adolescents, and families exposed to torture and related trauma. In: Gerrity E, Keane TM, Tuma F, eds. The mental health consequences of torture, New York: Plenum Publishers, 2001:211-25.

33 Williams C, Westermeyer J. Refugee mental health in resettlement countries. Washington, DC: Hemisphere Publishing Corporation, 1986

34 Howard M, Hodes M. Psychopathology, adversity, and service utilization of young refugees. J Am Acad Child Adolesc Psychiatry 2000;39:368-77.

35 Mortimore $\mathbf{P}$. The positive effects of schooling. In: Rutter $M$, ed. Psychosocial disturbances in young people: challenges for prevention. Cambridge: Cambridge University Press, 2001:333-63.

36 Wood D, Halfon N, Scarlata D, et al. Impact of family relocation on children's growth, development, school function, and behavior. JAMA $1993 ; 270: 1334-8$
37 Werner EE, Smith RS. Vulnerable but invincible: a longitudinal study of resilient children and youth. New York: McGraw Hill, 1982.

38 Lefcourt HM, Martin RA, Saleh EH. Locus of control and social support: interactive moderators of stress. J Pers Soc Psychol 1984;47:378-89.

39 Dobson J, Koser K, Mclaughlan G, et al. International migration and the United Kingdom. Recent patterns and trends. Final report to Home Office December 2001. RDS Occasional Paper no. 75. London: Home Office, Communication Development Unit, Research, Development and Statistics Directorate, 2001

40 National Asylum Support Service and Immigration and Nationality Directorate. Report of the Operational Reviews of the Voucher and Dispersal Schemes of the National Asylum Support Service. London: Home Office, 2001.

41 Seidman E, Allen L, Aber JL, et al. The impact of school transitions in early adolescence on the self-system and perceived social context of poor urban youth. Child Dev 1994;65:507-22.

42 van den Oord EJ, Rispens J. Differences between school classes in preschoolers' psychosocial adjustment: evidence for the importance of children's interpersonal relations. J Child Psychol Psychiatry 1999:40:417-30.

43 Rudolph KD, Lambert FS, Clark AG, et al. Negotiating the transition to middle school: the role of self-regulatory processes. Child Dev $2001 ; 72: 929-46$

44 United Nations. Study of the impact of armed conflict on children (the Machel Study). New York: United Nations, 1996.

45 United Nations. Convention Relating to the Status of Refugees, Resolution 429 (V), 1951

46 United Nations. Universal Declaration of Human Rights (Resolution 217 A (III)), 1948

47 United Nations. United Nations Convention on the Rights of the Child. United Nations General Assembly (Resolution 44/25), 1989.

48 Canadian Government. Child guidelines. irb.gc.ca/legal/guidline/ childref/index_e.stm, 1996.

49 Sack W, Angell R, Kinzie JD, et al. The psychiatric effects of massive trauma on Cambodian children. J Am Acad Child Adolesc Psychiatry 1986;25:370-5.

50 Zivcic I. Emotional reactions of children to war stress in Croatia. J Am Acad Child Adolesc Psychiatry 1993;32:709-13.

51 Hodes M. Refugee children. BM 1998;316:793-4.

52 Punamaki R. Factors affecting the mental health of Palestinian children exposed to political violence. Int J Mental Health 1989;18:63-79.

53 Realmuto G-M, Masten A, Carole L-F, et al. Adolescent survivors of massive childhood trauma in Cambodia: life events and current symptoms. J Trauma Stress 1992;5:589-99.

54 Westermeyer J. DSM-III psychiatric disorders among Hmong refugees in the United States: a point prevalence study. Am J Psychiatry 1988; 145: 197-202.

55 Ekblad S. Viktigt folia upp asylsokande barn. Riskfaktorerna andras under krisfaserna. [Importance of follow-up of refugee children. Risk factors are changing during the different phases of the crisis]. Lakartidningen 1994;91:4012-14,4017. 